\title{
Application of Bacillus species for controlling root-knot nematode Meloidogyne incognita in eggplant
}

\author{
Wafaa M. A. El-Nagdi and Hassan Abd-El-Khair
}

\begin{abstract}
Background: Eggplant (Solanum melongena L.) is one of the important vegetable crops infected by Meloidogyne incognita all over the world, including Egypt. Chemical nematicides frequently cause environmental pollution and toxic hazards to human, plants, and animals; certain biocontrol agents that are environmentally friendly and safe to humans and animals were tested against the root-knot nematode Meloidogyne incognita in eggplant.

Objective: This work is aimed to determine the nematicidal activity of Bacillus spp., viz., B. subtilis and B. pumilus, against $M$. incognita in three separated experiments to study their ability in controlling $M$. incognita and in improving the growth parameters of eggplants. Bacillus spp. were applied as single or in combination (experiment I), single treatment at different doses (experiment II), and different times (three times) of application (experiment III).

Results: The results of experiment I revealed that Bacillus sp. + B. subtilis significantly reduced the second-stage juvenile $\left(J_{2}\right)$ in soil and galls and egg masses in roots, while Bacillus sp. + B. pumilus significantly reduced $J_{2}$ in roots. Bacillus spp. in pairs were more effective against M. incognita. In experiment II, Bacillus sp. (40 ml) significantly reduced the $J_{2}$ in soil and galls and egg masses in roots, while $B$. pumilus $(40 \mathrm{ml})$ significantly reduced the $J_{2}$ in roots. The nematicidal activity of Bacillus spp. was increased by increasing the applied dose. In experiment III, $B$. subtilis, when applied three times, significantly reduced the $J_{2}$ in soil and the $J_{2}$ and galls in roots, while $B$. pumilus (applied three times) significantly reduced the egg masses in roots. All Bacillus spp. treatments highly increased the tested growth parameters compared to the controls.

Conclusions: The tested biocontrol agents used more than once or in combination are more effective than those used only once in controlling nematode parameters in eggplant under greenhouse conditions with a consequent increase in eggplant growth. These bacterial isolates need to be studied under different field conditions for confirmation.
\end{abstract}

Keywords: Application, Bacillus spp., Eggplant, Meloidogyne incognita, Pots experiment

\section{Background}

Eggplant (Solanum melongena L.) is one of the important vegetables grown over the world as well as in Egypt for producing fresh eggplant fruits (Usman and Siddiqui 2012). Meloidogyne incognita is a microscopic obligate soil-borne pathogen that feeds in eggplant roots and causes significant losses of yield. Application of chemicals causes ecosystem pollution. Therefore, applications of plant growthpromoting rhizobacteria (PGPR), such as Bacillus spp., can

\footnotetext{
* Correspondence: wafaaelnagdi@yahoo.com

Plant Pathology Department, Nematology Unit, National Research Centre, Dokki, Cairo 12622, Egypt
}

produce nematicidal metabolites and a promising tool for controlling nematodes and decrease the hazard due to chemical applications (Abbais et al. 2014; Ahemad and Kibret 2014; Sivasakthi et al. 2014). PGPR also can promote the plant growth parameters by secreting various regulatory compounds in the vicinity of the rhizosphere $(\mathrm{Gu}$ et al. 2007; Karmani et al. 2011). Application of cultural filtrates of Bacillus subtilis, as soil drench, reduced nematode parameters in eggplant roots in the greenhouse experiment (El-Nagdi and Abd-El-Khair 2008). Bacillus coagulans when applied with vermicompost or Glomus aggregatum decreased the root-knot nematode population and 
improved the plant growth of tomato cv. Pusa Ruby (Serfoji et al. 2010). B. subtilis and Trichoderma harzianum, alone or in combination, could suppress the M. incognita, viz. number of galls, immature stages, number of secondstage juveniles $\left(\mathrm{J}_{2}\right)$, and total final population of nematode, and enhance the growth parameters of eggplant cv. Patra in the greenhouse (Farfour and El-Ansary 2013). B. subtilis, B. thuringiensis, Psudomonas fluorescens, and Serratia marcescens, alone or as a mixture, inhibited egg-hatching and $\mathrm{J}_{2}$ of Meloidogyne javanica and highly reduced the numbers of galls and egg masses per root system and $\mathrm{J}_{2} /$ 250 soil as well as increased the dry weights of root and shoot in eggplants (Mokbel and Alharbi 2014). Bacillus weihenstephanensis produced the most effect against $M$. incognita in infected tomato through laboratory and glasshouse experiments. The bacterium highly reduced the $\mathrm{J}_{2}$ population in soil and roots and gall index, and it could increase fruit yield in tomatoes (Tamalika et al., 2014). The rhizospheric bacteria, viz. S. marcescens, P. fluorescens, and B. thuringiensis (BT14), had antagonistic effects against M. incognita (Zaghloul et al. 2015). B. subtilis and $B$. pumilus, alone or in combination, significantly reduced the numbers of $\mathrm{J}_{2}$ in soil and roots, females, galls, and eggmasses of $M$. incognita in pea. Treatments also significantly increased the growth parameters of pea plants, viz. shoot length, shoot fresh, and dry weight, leaf numbers, and pod fresh and dry weight (El-Nagdi et al. 2018). Application of B. subtilis, B. pumilus, and P. fluorescens, single or combined, controlled $M$. incognita, infecting cowpea cv. Baladi under greenhouse conditions, where most nematode reductions were obtained with $P$. fluorescens, followed by $P$. fluorescens $+B$. subtilis and P. fluorescens + B. subtilis + B. pumilus, respectively (El-Nagdi et al. 2019).

Therefore, this work is aimed to determine the nematicidal activity of Bacillus spp., viz., B. subtilis and $B$. pumilus, against $M$. incognita in three separated experiments to study their ability for controlling $M$. incognita and in the improvement of the growth parameters of eggplants. Bacillus spp. were applied as single or in combination (experiment I), single treatment at different doses (experiment II), and different times (three times) of application (experiment III).

\section{Methods}

\section{Preparation of the root-knot nematode inocula}

The roots of eggplants naturally infected with the rootknot nematode were collected from open fields. Egg masses of infected roots were extracted by using a sodium hypochlorite solution (Hussey and Barker 1973). A single egg-mass culture of the nematode was established and reared in eggplant cv. Pusa Purple Long in a greenhouse at $30 \pm 5^{\circ} \mathrm{C}$. Adult females were used to identify the nematode species by the morphological characteristics according to the female perineal pattern (Taylor and Sasser 1978). Second-stage juveniles $\left(J_{2}\right)$ were collected daily and stored at $15^{\circ} \mathrm{C}$, where it was applied in the experiments at less than 5 days old.

\section{Bacillus spp. strains}

Bacillus spp. strains, viz., B. subtilis and B. pumilus, were isolated from bean plant rhizospheres in Egypt, and then they were identified according to morphological, cultural, and biochemical characteristics using standard bacteriological methods in the Department of Plant Pathology, National Research Centre, and were applied in this study. The bioassay of tested Bacillus spp. against $\mathrm{J}_{2}$ of $M$. incognita was examined in pervious study (Abd-El-Khair et al. 2016).

\section{Preparation of Bacillus spp. inocula}

For the preparation of bacterial inoculums, each Bacillus sp. was separately inoculated in a conical flask $(250 \mathrm{ml})$ containing $200 \mathrm{ml}$ of nutrient sucrose (2\%) broth [NGB] medium [beef extract, $3.0 \mathrm{~g}$; peptone, $5.0 \mathrm{~g}$; glucose, 10.0 g; $1.0 \mathrm{l}$ of distilled water, and adjusted $\mathrm{pH}$ at $7.2 \pm 0.2$ ]. The inoculated flasks were incubated at $28^{\circ} \mathrm{C}$ for 4 days. Then, the bacterial inoculum of each bacterium was adjusted to $10^{7-9}$ colony-forming unit (CFU)/ml by turbidity method. Bacillus sp. inoculum was applied as a mixture of bacterial cells and cultural filtrates.

\section{Pot experiment design}

Three experiments were separately conducted to study the nematicidal activity of each Bacillus sp., B. subtilis and $B$. pumilus, against $M$. incognita in pots under greenhouse conditions in DPP, NRC. Four-week-old eggplant seedlings cv. Pusa Purple Long was transplanted in plastic pots (20-cm diameter) containing $2 \mathrm{~kg}$ of a sun-sterilized sandy and loamy soil mixture $(\mathrm{V}: \mathrm{V})$. One eggplant transplant was sown in each pot. Each pot was inoculated with 1000 newly hatched $\mathrm{J}_{2}$ of $M$. incognita in four holes made around each plant. Four pots were used as replicates for each treatment as well as the controls. The pots in each experiment were arranged according to a completely randomized design on a bench in the glasshouse maintained at $25 \pm 5^{\circ} \mathrm{C}$. The plants were irrigated regularly.

\section{Experiment I}

This experiment was conducted to study the nematicidal activity of three Bacillus spp. as single or in combination treatments against $M$. incognita parameters. The experiment includes ten treatments as follows: (1) Bacillus sp.,

(2) B. subtilis, (3) B. pumilus, (4) Bacillus sp. + B. subtilis,

(5) Bacillus sp. + B. pumilus, (6) B. subtilis + B. pumilus,

(7) Bacillus sp. + B. subtilis + B. pumilus, (8) Micronima ${ }^{\circ}$,

(9) NGB medium only, and (10) M. incognita only. After 
3 days of nematode inoculation, each pot was treated with $20 \mathrm{ml}$ each of bacterial inoculum around the plant. The control pots were separately treated with $20 \mathrm{ml}$ of Micronima ${ }^{\circ}, 20 \mathrm{ml}$ medium only and without any treatment (nematode only), respectively.

\section{Experiment II}

This experiment was designed to study the nematicidal activity of three Bacillus spp. against $M$. incognita when applied as a single treatment at different doses of 20,30, and $40 \mathrm{ml} /$ pot. The experiment includes 12 treatments as follows: (1) Bacillus sp. (20 ml/pot), (2) Bacillus sp. (30 ml/pot), (3) Bacillus sp. (40/pot), (4) B. subtilis (20 $\mathrm{ml} / \mathrm{pot}$ ), (5) B. subtilis ( $30 \mathrm{ml} / \mathrm{pot}),(6)$ B. subtilis (40/ pot), (7) B. pumilus (20 ml/pot), (8) B. pumilus $(30 \mathrm{ml} /$ pot), (9) B. pumilus (40 ml/pot), (10) Micronima ${ }^{\circ}$, (11) NGB medium only, and (12) nematode only. After 3 days of nematode inoculation, the eggplant plants were treated with each bacterial inoculum at tested doses around the eggplant. For control, pots were separately treated with $20 \mathrm{ml}$ of Micronima ${ }^{\circ}, 20 \mathrm{ml} \mathrm{NGB}$ medium only and nematode only, respectively.

\section{Experiment III}

This experiment was conducted to study the nematicidal activity of three Bacillus spp. as application times (three times) of a single treatment against M. incognita. All Bacillus spp. were applied three times (one, two, and three times/pot) with a 7-day interval between each treatment and another. The experiment includes 12 treatments as follows: (1) Bacillus sp. (one time/pot), (2) Bacillus sp. (two times/pot), (3) Bacillus sp. (three times/pot), (4) B. subtilis (one time/pot), (5) B. subtilis (two times/pot), (6) B. subtilis (three times/pot), (7) B. pumilus (one time/pot), (8) B. pumilus (two times/pot), (9) B. pumilus (three times/pot), (10) Micronima ${ }^{\circ}$ (11) NGB medium only, and (12) nematode only. After 3 days of nematode inoculation, the eggplant plants were treated with each bacterial inoculum at tested doses around the eggplant. For control, the pots were separately treated with $20 \mathrm{ml}$ of Micronima ${ }^{\oplus}, 20 \mathrm{ml}$ medium only and nematode only, respectively.

\section{Effects of Bacillus spp. on M. incognita parameters}

After 6 months of nematode inoculation, the nematicidal activity of Bacillus spp. against M. incognita parameters, viz. the numbers of $J_{2}$ in soil, $J_{2}$ in roots, and both galls and egg masses in the entire root apparatus of eggplants (four plant roots per treatment), were recorded. The number of $\mathrm{J}_{2}$ in the soil was extracted using a sieving and decanting technique (Barker, 1985). The roots of eggplants were carefully uprooted and washed thoroughly with running tap water and then a number of $\mathrm{J}_{2}$ in roots $(5 \mathrm{~g})$ were recorded. All $\mathrm{J}_{2}$ numbers of nematodes were counted under a light microscope. Numbers of galls and egg masses on the entire root system of eggplant were also recorded.

\section{Effects of Bacillus spp. on growth parameters of eggplants}

The role of Bacillus spp. in the improvement of the plant growth parameters, viz. shoot length (centimeter), fresh and dry shoot weights (grams), fresh root weight (grams), and leaf number per plant, was recorded after 6 months of nematode inoculation. Four eggplants were used as replicates.

\section{Statistical analysis of data}

Statistical analysis of the obtained data was performed through Computer Statistical Package (COSTAT) User Manual Version 3.03, Barkley Co., a computer-based program. Analyses include analysis of variance (ANOVA) procedures (Snedecor and Cochran 1999). Duncan's multiple range test (DMRT) was applied to compare the means for each treatment at $5 \%$ level of probability.

\section{Results \\ Effects of Bacillus spp. on M. incognita parameters Experiment I}

Results show that Bacillus spp. reduced the $\mathrm{J}_{2}$ numbers in soil in the ranges of $2.55 \log _{10}-3.10 \log _{10}$, when applied as single or in combination, compared to $2.36 \log _{10}, 3.23$ $\log _{10}$, and $3.34 \log _{10}$ with Micronima ${ }^{\circ}$, medium only, and nematode only, respectively. The percentages of reduction were in the ranges of $42-84 \%\left(\mathrm{~J}_{2}\right.$ in soil), compared to 89 and $23 \%$ with Micronima and medium only, respectively. The treatment of Bacillus sp. $+B$. subtilis significantly reduced the $\mathrm{J}_{2}$, followed by treatments of $B$. subtilis $+B$. pumilus, B. subtilis, Bacillus sp. + B. pumilus, Bacillus sp. + B. subtilis $+B$. pumilus, Bacillus sp. and B. pumilus, respectively (Table 1 ). The numbers of $\mathrm{J}_{2}$ in roots were in the ranges of $1.90 \log _{10}-2.48 \log _{10}$ with Bacillus spp., compared to $2.19 \log _{10}, 3.05 \log _{10}$ and $3.23 \log _{10}$ with Micronima ${ }^{\circ}$, medium only and nematode only, respectively. Bacillus spp. reduced the $J_{2}$ in roots in the ranges of 82-95\%, compared to 91 and $35 \%$ with Micronima and medium only, respectively. Bacillus sp. + B. pumilus significantly reduced the $J_{2}$ in roots, followed by $B$. pumilus, Bacillus sp. + B. subtilis, Bacillus sp. + B. subtilis $+B$. pumilus, B. subtilis + B. pumilus, B. subtilis, and Bacillus sp., respectively (Table 1 ).

Bacillus spp. reduced the numbers of galls in eggplant roots in the ranges of $0.89 \log _{10}-1.53 \log _{10}$, compared to $0.96 \log _{10}, 1.69 \log _{10}$, and $1.85 \log _{10}$ with Micronima ${ }^{\circ}$, medium only, and nematode only, respectively. Bacillus spp. reduced the galls in the ranges of $52-89 \%$, compared to $87 \%$ and $30 \%$ with Micronima ${ }^{\circ}$ and medium only, respectively. Bacillus sp. + B. subtilis significantly reduced the galls, followed by $B$. subtilis $+B$. pumilus, 
Table 1 Effects of Bacillus spp., as single or in combination treatments at a dose of $20 \mathrm{ml} / \mathrm{pot}$, on nematode parameters of Meloidogyne incognita-infected eggplants in pots (experiment I)

\begin{tabular}{|c|c|c|c|c|c|c|c|c|}
\hline \multirow[t]{3}{*}{ Bacillus spp. } & \multicolumn{8}{|c|}{ Meloidogyne incognita parameters } \\
\hline & \multicolumn{2}{|c|}{$\mathrm{J}_{2}$ in soil $(200 \mathrm{~g})$} & \multicolumn{2}{|c|}{$\mathrm{J}_{2}$ in roots $(5 \mathrm{~g})$} & \multicolumn{2}{|l|}{ No. galls } & \multicolumn{2}{|c|}{ No. egg masses } \\
\hline & Count $\left(\log _{10}\right)$ & Red. \% & Count $\left(\log _{10}\right)$ & Red. \% & Count $\left(\log _{10}\right)$ & Red. \% & Count $\left(\log _{10}\right)$ & Red. \% \\
\hline Nematode only & $3.34^{a *}$ & - & $3.23^{\mathrm{a}}$ & - & $1.85^{\mathrm{a}}$ & - & $1.75^{\mathrm{a}}$ & - \\
\hline NGB medium only & $3.23^{\mathrm{ab}}$ & 23 & $3.05^{b}$ & 35 & $1.69^{\mathrm{ab}}$ & 30 & $1.56^{\mathrm{b}}$ & 36 \\
\hline Micronima ${ }^{\oplus}$ & $2.36^{\mathrm{f}}$ & 89 & $2.19^{\mathrm{ef}}$ & 91 & $0.96^{\mathrm{fg}}$ & 87 & $0.79^{\mathrm{ef}}$ & 89 \\
\hline Bacillus sp. & $2.96^{\mathrm{C}}$ & 58 & $2.48^{\mathrm{c}}$ & 82 & $1.53^{\mathrm{bc}}$ & 52 & $1.41^{\mathrm{bc}}$ & 55 \\
\hline B. subtilis & $2.67^{\mathrm{de}}$ & 78 & $2.43^{c}$ & 84 & $1.53^{\mathrm{bc}}$ & 52 & $1.35^{\mathrm{c}}$ & 61 \\
\hline B. pumilus & $3.10^{\mathrm{bc}}$ & 42 & $2.09^{f}$ & 93 & $1.27^{\mathrm{de}}$ & 73 & $1.14^{d}$ & 75 \\
\hline Bacillus sp. + B. subtilis & $2.55^{\mathrm{e}}$ & 84 & $2.23^{\mathrm{ef}}$ & 90 & $0.89^{9}$ & 89 & $0.72^{f}$ & 91 \\
\hline Bacillus sp. + B. pumilus & $2.73^{d}$ & 75 & $1.90^{9}$ & 95 & $1.12^{\mathrm{ef}}$ & 80 & $0.95^{\mathrm{e}}$ & 84 \\
\hline B. subtilis $+B$. pumilus & $2.64^{\mathrm{de}}$ & 80 & $2.39^{\mathrm{cd}}$ & 86 & $1.06^{\mathrm{fg}}$ & 83 & $0.92^{\mathrm{e}}$ & 85 \\
\hline Bacillus sp. + B. subtilis + B. pumilus & $2.78^{d}$ & 72 & $2.27^{\mathrm{de}}$ & 89 & $1.42^{c d}$ & 63 & $1.30^{c d}$ & 65 \\
\hline
\end{tabular}

Means followed by different superscript letters are significantly different according to Duncan's multiple range test at $P \leq 0.05$

Red. reduction

*Means are averages of four replicates

Bacillus sp. + B. pumilus, B. pumilus, Bacillus sp. + B. subtilis $+B$. pumilus, Bacillus sp., and B. subtilis, respectively. The numbers of egg masses ranged from $0.72 \log _{10}$ to $1.41 \log _{10}$ with Bacillus spp., compared to $0.79 \log _{10}$, $1.56 \log _{10}$, and $1.75 \log _{10}$ with Micronima ${ }^{\circ}$, medium only, and nematode only, respectively. Bacillus spp. reduced the numbers of egg masses in the ranges of 55$91 \%$, compared to $89 \%$ and $36 \%$ with Micronima and medium only, respectively. Bacillus sp. + B. subtilis significantly reduced the egg masses, followed by $B$. subtilis $+B$. pumilus, Bacillus sp. + B. pumilus, B. pumilus, Bacillus sp. + B. subtilis $+B$. pumilus, B. subtilis, and Bacillus sp., respectively (Table 1).

\section{Experiment II}

The results revealed that the numbers of $\mathrm{J}_{2}$ in soil of eggplants ranged from $2.00 \log _{10}$ to $3.11 \log _{10}$ with an application of Bacillus spp. as a single treatment at different doses, i.e., 20,30, and $40 \mathrm{ml} /$ pot, compared to $2.36 \log _{10}, 3.23 \log _{10}$, and 3.34 $\log _{10}$ with Micronima ${ }^{\circ}$, medium only, and nematode only, respectively. Bacillus spp. reduced the $J_{2}$ in the ranges of $42-95 \%$, compared to $89 \%$ and $23 \%$ with Micronima and medium only, respectively. Bacillus sp. $(40 \mathrm{ml})$ significantly reduced the $\mathrm{J}_{2}$, followed by B. subtilis $(40 \mathrm{ml})$, B. subtilis $(30 \mathrm{ml})$, Bacillus sp. $(30 \mathrm{ml})$, B. subtilis $(20 \mathrm{ml})$, B. pumilus $(40$ $\mathrm{ml})$, B. pumilus $(30 \mathrm{ml})$, Bacillus sp. $(20 \mathrm{ml})$, and $B$. pumilus $(20 \mathrm{ml})$, respectively. The numbers of $\mathrm{J}_{2}$ in roots ranged from $1.77 \log _{10}$ to $2.47 \log _{10}$ with Bacillus spp., compared to $2.19 \log _{10}, 3.05 \log _{10}$, and $3.23 \log _{10}$ with Micronima ${ }^{\circ}$, medium only, and nematode only, respectively. Bacillus spp. reduced the $\mathrm{J}_{2}$ /roots in the ranges of $82-97 \%$, compared to $91 \%$ and $35 \%$ with Micronima ${ }^{\circ}$ and medium only, respectively. B. pumilus $(40 \mathrm{ml})$ significantly reduced the $\mathrm{J}_{2}$ in roots, followed by $B$. subtilis $(40 \mathrm{ml})$, B. pumilus $(30 \mathrm{ml})$, Bacillus sp. $(40 \mathrm{ml}), B$. pumilus $(20 \mathrm{ml})$, B. subtilis $(30 \mathrm{ml})$, Bacillus sp. $(30 \mathrm{ml})$, B. subtilis $(20 \mathrm{ml})$, and Bacillus sp. $(20 \mathrm{ml})$, respectively (Table 2).

The numbers of galls ranged from $0.69 \log _{10}$ to 1.53 $\log _{10}$ with Bacillus sp. treatments, compared to 0.96 $\log _{10}, 1.69 \log _{10}$, and $1.85 \log _{10}$ with Micronima ${ }^{\circ}$, medium only, and nematode only, respectively. Bacillus spp. reduced the galls in the ranges of $50-93 \%$, compared to $87 \%$ and $30 \%$ with Micronima a and medium only, respectively. Bacillus sp. (40 ml) significantly reduced the galls, followed by B. subtilis $(40 \mathrm{ml}), B$. subtilis $(30 \mathrm{ml})$, B. pumilus $(40 \mathrm{ml})$, B. pumilus $(30 \mathrm{ml})$, B. pumilus $(20 \mathrm{ml})$, Bacillus sp. $(30 \mathrm{ml})$, Bacillus sp. $(20 \mathrm{ml})$, and B. subtilis $(20 \mathrm{ml})$, respectively. The egg masses' numbers ranged from $0.49 \log _{10}$ to $1.44 \log _{10}$ with Bacillus spp., compared to the galls of $0.82 \log _{10}, 1.57 \log _{10}$, and 1.76 $\log _{10}$ with Micronima ${ }^{\circ}$, medium only, and nematode only, respectively. Bacillus spp. reduced the number of egg masses in the ranges of $52-94 \%$, compared to $89 \%$ and $36 \%$ with Micronima and medium only, respectively. Bacillus sp. $(40 \mathrm{ml})$ significantly reduced the egg masses, followed by B. subtilis $(40 \mathrm{ml})$, B. pumilus $(40 \mathrm{ml})$, B. subtilis $(30 \mathrm{ml})$, B. pumilus $(30 \mathrm{ml})$, B. pumilus $(20 \mathrm{ml})$, B. subtilis $(20 \mathrm{ml})$, Bacillus sp. $(30 \mathrm{ml})$, and Bacillus sp. $(20 \mathrm{ml})$, respectively (Table 2$)$.

\section{Experiment III}

The numbers of $\mathrm{J}_{2}$ in soil of eggplants ranged from 2.17 $\log _{10}$ to $3.11 \log _{10}$ with Bacillus spp. when applied three times with a 7-day interval between each treatment and another, compared to $2.37 \log _{10}, 3.23 \log _{10}$, and 3.34 $\log _{10}$ with Micronima ${ }^{\circ}$, medium only, and nematode 
Table 2 Effects of Bacillus spp., as a single treatment at doses of 20, 30, and $40 \mathrm{ml} /$ pot, on nematode parameters of Meloidogyne incognita-infected eggplants in pots (experiment II)

\begin{tabular}{|c|c|c|c|c|c|c|c|c|c|}
\hline \multirow{3}{*}{\multicolumn{2}{|c|}{ Bacillus spp. }} & \multicolumn{8}{|c|}{ Meloidogyne incognita parameters } \\
\hline & & \multicolumn{2}{|c|}{$\mathrm{J}_{2}$ in soil $(200 \mathrm{~g})$} & \multicolumn{2}{|c|}{$\mathrm{J}_{2}$ in roots $(5 \mathrm{~g})$} & \multicolumn{2}{|l|}{ No. galls } & \multicolumn{2}{|c|}{ No. egg masses } \\
\hline & & Count $\left(\log _{10}\right)$ & Red. \% & Count $\left(\log _{10}\right)$ & Red. \% & Count $\left(\log _{10}\right)$ & Red. \% & Count $\left(\log _{10}\right)$ & Red. \% \\
\hline \multicolumn{2}{|c|}{ Nematode only } & $3.34^{\mathrm{a}}$ & - & $3.23^{\mathrm{a}}$ & - & $1.86^{\mathrm{a}}$ & - & $1.76^{\mathrm{a}}$ & - \\
\hline \multicolumn{2}{|c|}{ NGB medium only } & $3.23^{\mathrm{a}}$ & 23 & $3.05^{\mathrm{b}}$ & 35 & $1.70^{\mathrm{a}}$ & 30 & $1.57^{\mathrm{b}}$ & 36 \\
\hline \multicolumn{2}{|l|}{ Micronima ${ }^{\oplus}$} & $2.36^{\mathrm{de}}$ & 89 & $2.19^{e f}$ & 91 & $0.98^{d}$ & 87 & $0.82^{\mathrm{fg}}$ & 89 \\
\hline \multirow[t]{3}{*}{ Bacillus sp. } & $20 \mathrm{ml}$ & $2.96^{\mathrm{abc}}$ & 59 & $2.47^{c}$ & 82 & $1.52^{\mathrm{b}}$ & 54 & $1.44^{\mathrm{bc}}$ & 52 \\
\hline & $30 \mathrm{ml}$ & $2.61^{c d}$ & 81 & $2.29^{\mathrm{de}}$ & 88 & $1.49^{\mathrm{b}}$ & 57 & $1.39^{\mathrm{bc}}$ & 57 \\
\hline & $40 \mathrm{ml}$ & $2.00^{e f}$ & 95 & $2.06^{f}$ & 93 & $0.69^{e}$ & 93 & $0.49^{h}$ & 94 \\
\hline \multirow[t]{3}{*}{ B. subtilis } & $20 \mathrm{ml}$ & $2.67^{c d}$ & 78 & $2.43^{c d}$ & 84 & $1.53^{\mathrm{b}}$ & 50 & $1.35^{\mathrm{cd}}$ & 60 \\
\hline & $30 \mathrm{ml}$ & $2.57^{\mathrm{cd}}$ & 83 & $2.19^{e f}$ & 91 & $0.96^{d}$ & 87 & $0.86^{f}$ & 87 \\
\hline & $40 \mathrm{ml}$ & $2.03^{e f}$ & 95 & $2.03^{f}$ & 94 & $0.93^{d}$ & 88 & $0.64^{g h}$ & 92 \\
\hline \multirow[t]{3}{*}{ B. pumilus } & $20 \mathrm{ml}$ & $3.11^{\mathrm{ab}}$ & 42 & $2.09^{f}$ & 93 & $1.30^{c}$ & 72 & $1.19^{\mathrm{de}}$ & 73 \\
\hline & $30 \mathrm{ml}$ & $2.74^{\mathrm{bcd}}$ & 75 & $2.35^{\mathrm{cd}}$ & 94 & $1.20^{c}$ & 78 & $1.07^{e}$ & 79 \\
\hline & $40 \mathrm{ml}$ & $2.72^{\mathrm{bcd}}$ & 76 & $1.77^{\mathrm{g}}$ & 97 & $1.01^{d}$ & 86 & $0.74^{f g}$ & 90 \\
\hline
\end{tabular}

Means followed by different superscript letters are significantly different according to Duncan's multiple range test at $P \leq 0.05$ Red. reduction

*Means are averages of four replicates

only, respectively. Bacillus spp. reduced $\mathrm{J}_{2}$ in soil in the ranges of $42-93 \%$, compared to $89 \%$ and $23 \%$ with Micronima ${ }^{\circ}$ and medium only, respectively. B. subtilis (three times of application) significantly reduced the $\mathrm{J}_{2}$, followed by B. subtilis (two times), B. pumilus (two times), B. pumilus (three times), B. subtilis (one time), Bacillus sp. (three times), Bacillus sp. (two times), Bacillus sp. (one time), and B. pumilus (one time), respectively. The numbers of $\mathrm{J}_{2}$ in roots ranged from $1.67 \log _{10}$ to $2.598 \log _{10}$ with Bacillus spp, compared to $2.19 \log _{10}, 3.05 \log _{10}$, and 3.24 $\log _{10}$ with Micronima ${ }^{\circ}$, medium only, and nematode only, respectively. Bacillus spp. reduced the $\mathrm{J}_{2}$ in roots in the ranges of $77-97 \%$, compared to $91 \%$ and $35 \%$ with Micronima $^{\circ}$ and medium only, respectively. B. subtilis (three times) significantly reduced the $\mathrm{J}_{2}$ in roots, followed by Bacillus sp. (three times), B. subtilis (two times), B. pumilus (three times), B. pumilus (two times), Bacillus sp. (two times), B. subtilis (one time), Bacillus sp. (one time), and $B$. pumilus (one time), respectively (Table 3 ).

The numbers of galls ranged from $0.63 \log _{10}$ to 1.55 $\log _{10}$ with Bacillus spp., compared to $0.99 \log _{10}, 1.70$ $\log _{10}$, and $1.86 \log _{10}$ with Micronima ${ }^{\circ}$, medium only, and nematode only, respectively. Bacillus spp. reduced galls in the ranges of $50-94 \%$, compared to $86 \%$ and $31 \%$ with Micronima and medium only. B. subtilis (three times) significantly reduced the galls, followed by B. subtilis (two times), B. pumilus (three times), B. pumilus (two times), Bacillus sp. (three times), Bacillus sp. (two times), B. pumilus (one time), Bacillus sp. (one time), and B. subtilis (one time), respectively. The number of egg masses ranged from $0.69 \log _{10}$ to $1.41 \log _{10}$ in roots with Bacillus spp., compared to $0.84 \log _{10}, 1.56$ $\log _{10}$, and $1.76 \log _{10}$ with Micronima ${ }^{\circ}$ medium only, and nematode only, respectively. Bacillus spp. reduced the egg masses in the ranges of $56-91 \%$, compared to $88 \%$ and $38 \%$ with Micronima ${ }^{\circ}$ and medium only, respectively. B. pumilus (three times) significantly reduced the egg masses, followed by $B$. subtilis (three times), $B$. subtilis (two times), B. pumilus (two times), Bacillus sp. (three times), B. pumilus (one time), Bacillus sp. (two times), B. subtilis (one time), and Bacillus sp. (one time), respectively (Table 3).

\section{Effects of Bacillus spp. on growth parameters Experiment I}

Bacillus spp., when applied as single or in combination treatment, improved the growth parameters of eggplants under greenhouse conditions (Table 4). The averages of the shoot length (SL) of eggplants were in the ranges of $35.00-59.00 \mathrm{~cm}$ with Bacillus spp., compared to 37.75 , 28.28 , and $22.75 \mathrm{~cm}$ with Micronima ${ }^{\circ}$, medium only, and nematode only, respectively. Bacillus sp. + B. subtilis significantly increased the SL of eggplants, followed by Bacillus sp. + B. pumilus, Bacillus sp. + B. subtilis $+B$. pumilus, B. subtilis $+B$. pumilus, B. pumilus, Bacillus sp., and B. subtilis, respectively. The averages of the fresh shoot weight (FSW) ranged from 26.60 to $58.60 \mathrm{~g}$ with Bacillus spp., compared to 26.13, 21.90, and $15.95 \mathrm{~g}$ with Micronima, medium only, and nematode only, respectively. Bacillus sp. + B. subtilis significantly increased the average of FSW, followed by Bacillus sp., $B$. subtilis, Bacillus sp. + B. subtilis $+B$. pumilus, $B$. 
Table 3 Effects of Bacillus spp., as single treatment at different application times at dose $20 \mathrm{ml} /$ pot, on nematode parameters of Meloidogyne incognita-infected eggplants in pots (experiment III)

\begin{tabular}{|c|c|c|c|c|c|c|c|c|c|}
\hline \multirow{3}{*}{\multicolumn{2}{|c|}{ Bacillus spp. }} & \multicolumn{8}{|c|}{ Meloidogyne incognita parameters } \\
\hline & & \multicolumn{2}{|c|}{$\mathrm{J}_{2}$ in soil $(200 \mathrm{~g})$} & \multicolumn{2}{|c|}{$\mathrm{J}_{2}$ in roots $(5 \mathrm{~g})$} & \multicolumn{2}{|l|}{ No. galls } & \multicolumn{2}{|c|}{ No. egg masses } \\
\hline & & Count $\left(\log _{10}\right)$ & Red. \% & Count $\left(\log _{10}\right)$ & Red. \% & Count $\left(\log _{10}\right)$ & Red. \% & Count $\left(\log _{10}\right)$ & Red. \% \\
\hline \multicolumn{2}{|c|}{ Nematode only } & $3.34^{\mathrm{a}}$ & - & $3.24^{\mathrm{a}}$ & - & $1.86^{\mathrm{a}}$ & - & $1.76^{\mathrm{a}}$ & - \\
\hline \multicolumn{2}{|c|}{ NGB medium only } & $3.23^{\mathrm{a}}$ & 23 & $3.05^{\mathrm{b}}$ & 35 & $1.70^{\mathrm{a}}$ & 31 & $1.56^{\mathrm{a}}$ & 38 \\
\hline \multicolumn{2}{|l|}{ Micronima ${ }^{\oplus}$} & $2.37^{\mathrm{fg}}$ & 89 & $2.19^{e f}$ & 91 & $0.99^{d}$ & 86 & $0.84^{\mathrm{fg}}$ & 88 \\
\hline \multirow[t]{3}{*}{ Bacillus sp. } & one time & $2.96^{\mathrm{c}}$ & 58 & $2.49^{\mathrm{cd}}$ & 82 & $1.54^{\mathrm{b}}$ & 51 & $1.41^{\mathrm{b}}$ & 56 \\
\hline & two times & $2.74^{d}$ & 75 & $1.31^{\mathrm{de}}$ & 88 & $1.29^{c}$ & 73 & $1.20^{c d}$ & 73 \\
\hline & three times & $2.72^{\mathrm{de}}$ & 76 & $1.79^{g h}$ & 96 & $1.18^{c}$ & 77 & $1.04^{\mathrm{de}}$ & 81 \\
\hline \multirow[t]{3}{*}{ B. subtilis } & one time & $2.69^{\text {de }}$ & 79 & $2.44^{\mathrm{cd}}$ & 84 & $1.55^{\mathrm{b}}$ & 50 & $1.36^{b c}$ & 60 \\
\hline & two times & $2.45^{f}$ & 87 & $1.87^{g h}$ & 96 & $0.83^{d}$ & 90 & $0.97^{\mathrm{ef}}$ & 84 \\
\hline & three times & $2.17^{\mathrm{h}}$ & 93 & $1.67^{\mathrm{h}}$ & 97 & $0.63^{\mathrm{e}}$ & 94 & $0.82^{\mathrm{fg}}$ & 89 \\
\hline \multirow[t]{3}{*}{ B. pumilus } & one time & $3.11^{\mathrm{b}}$ & 42 & $2.59^{c}$ & 77 & $1.28^{c}$ & 73 & $1.15^{\mathrm{d}}$ & 75 \\
\hline & two times & $2.61^{e}$ & 82 & $2.17^{e f}$ & 91 & $1.20^{c}$ & 78 & $0.96^{\mathrm{ef}}$ & 84 \\
\hline & three times & $2.29^{9}$ & 81 & $2.09^{f}$ & 93 & $0.93^{d}$ & 88 & $0.69^{9}$ & 91 \\
\hline
\end{tabular}

Means followed by different superscript letters are significantly different according to Duncan's multiple range test at $P \leq 0.05$ Red. reduction

*Means are averages of four replicates

subtilis + B. pumilus, Bacillus sp. + B. subtilis, and B. pumilus, respectively. Results showed that the averages of the dry shoot weight (DSW) of eggplants ranged from 6.06 to $9.39 \mathrm{~g}$ with Bacillus spp., compared to the DSW of 3.36, 2.63, and $2.55 \mathrm{~g}$ with Micronima ${ }^{\circ}$, medium only, and nematode only, respectively. Bacillus sp. + B. subtilis also significantly increased the average of the DSW, followed by $B$. subtilis $+B$. pumilus, Bacillus sp. $+B$. subtilis + B. pumilus, Bacillus sp. + B. subtilis, B. subtilis, Bacillus sp., and B. pumilus, respectively (Table 4).
The averages of the eggplant leaf number ranged from 27.50 to 37.00 leaves with Bacillus spp., compared to 23.50, 21.25, and 16.75 leaves with Micronima ${ }^{\circ}$, medium only, and nematode only, respectively. Bacillus sp. $+B$. subtilis significantly increased the leaf number, followed by B. subtilis, B. pumilus, Bacillus sp., Bacillus sp. $+B$. pumilus, B. subtilis + B. pumilus, and Bacillus sp. + B. subtilis $+B$. pumilus, respectively The averages of the fresh root weight (FRW) of eggplants ranged from 6.10 to $13.13 \mathrm{~g}$ with Bacillus spp., compared to $5.08,4.35$, and

Table 4 Effects of Bacillus spp., single or in combination treatments at dose of $20 \mathrm{ml} /$ pot, on vegetative parameters of eggplants in pots (Experiment, I)

\begin{tabular}{|c|c|c|c|c|c|c|c|c|c|c|}
\hline \multirow[t]{3}{*}{ Bacillus spp. } & \multicolumn{10}{|c|}{ Vegetative parameters } \\
\hline & \multicolumn{2}{|c|}{ Shoot length $(\mathrm{cm})$} & \multicolumn{2}{|c|}{ Shoot fresh weight (g) } & \multicolumn{2}{|c|}{ Shoot dry weight (g) } & \multicolumn{2}{|l|}{ Leaf no. } & \multicolumn{2}{|c|}{ Fresh root weight $(\mathrm{g})$} \\
\hline & Length (cm) & Inc. $\%$ & Weight (g) & Inc. \% & Weight (g) & Inc. $\%$ & NO. & Inc. $\%$ & Weight (g) & Inc. \% \\
\hline Nematode only & $22.75^{d_{*}}$ & - & $15.95^{d}$ & - & $2.55^{c}$ & - & $16.75^{b}$ & - & $4.28^{b}$ & - \\
\hline NGB medium only & $28.25^{\mathrm{cd}}$ & 24 & $21.90^{c d}$ & 37 & $2.63^{f}$ & 3 & $21.25^{b}$ & 27 & $4.35^{b}$ & 2 \\
\hline Micronima ${ }^{\oplus}$ & $37.75^{b c}$ & 114 & $26.13^{b c}$ & 64 & $3.36^{e}$ & 32 & $23.50^{a b}$ & 40 & $5.08^{b}$ & 19 \\
\hline Bacillus sp. & $36.25^{\mathrm{bcd}}$ & 59 & $34.95^{b}$ & 119 & $4.04^{d}$ & 58 & $28.25^{a b}$ & 69 & $7.68^{a b}$ & 79 \\
\hline B. subtilis & $35.00^{\mathrm{bcd}}$ & 54 & $33.45^{b}$ & 110 & $6.06^{c}$ & 138 & $29.75^{a b}$ & 78 & $7.68^{\mathrm{ab}}$ & 79 \\
\hline B. pumilus & $40.00^{b c}$ & 76 & $26.70^{\mathrm{bc}}$ & 67 & $3.26^{\mathrm{e}}$ & 28 & $29.50^{a b}$ & 76 & $6.30^{\mathrm{b}}$ & 47 \\
\hline Bacillus sp. + B. subtilis & $59.00^{a}$ & 159 & $58.60^{a}$ & 267 & $9.39^{\mathrm{a}}$ & 268 & $37.00^{\mathrm{a}}$ & 121 & $13.13^{\mathrm{a}}$ & 207 \\
\hline Bacillus sp. + B. pumilus & $50.00^{a b}$ & 120 & $27.98^{b c}$ & 75 & $6.30^{b}$ & 147 & $27.75^{a b}$ & 66 & $9.23^{a b}$ & 116 \\
\hline B. subtilis + B. pumilus & $43.25^{b}$ & 90 & $28.28^{b c}$ & 77 & $6.34^{b}$ & 149 & $27.50^{\mathrm{ab}}$ & 64 & $6.10^{b}$ & 43 \\
\hline Bacillus sp. + B. subtilis + B. pumilus & $48.75^{\mathrm{ab}}$ & 114 & $29.38^{b c}$ & 84 & $6.33^{b}$ & 148 & $23.50^{\mathrm{ab}}$ & 40 & $9.10^{\mathrm{ab}}$ & 113 \\
\hline
\end{tabular}

Means followed by different superscript letters are significantly different according to Duncan's multiple range test at $P \leq 0.05$ Inc. increase

*Means are averages of four replicates 
$4.28 \mathrm{~g}$ with Micronima ${ }^{\circ}$ medium only, and nematode only, respectively. Bacillus sp. + B. subtilis significantly increased the FRW, followed by Bacillus sp. + B. pumilus, Bacillus sp. + B. subtilis $+B$. pumilus, Bacillus sp., Bacillus sp., B. subtilis, B. pumilus, and B. subtilis $+B$. pumilus, respectively (Table 4 ).

\section{Experiment II}

Bacillus sp. treatments, when applied as a single treatment at doses of 20,30 , and $40 \mathrm{ml} /$ pot, improved the growth parameters of eggplants under greenhouse conditions (Table 5). The averages of the SL of eggplants ranged from 35.50 to $57.50 \mathrm{~cm}$ with Bacillus spp., compared to $38.25,28.55$, and $23.25 \mathrm{~cm}$ with Micronima ${ }^{\circ}$, medium only, and nematode only, respectively. B. pumilus $(40 \mathrm{ml})$ significantly increased the average of the SL of plants, followed by B. subtilis ( $40 \mathrm{ml})$, B. pumilus (30 $\mathrm{ml})$, B. pumilus $(20 \mathrm{ml})$, Bacillus sp. $(40 \mathrm{ml})$, B. subtilis (30 ml), Bacillus sp. (30 ml), Bacillus sp. $(20 \mathrm{ml})$, and $B$. subtilis $(20 \mathrm{ml})$, respectively. The averages of the FSW of eggplants ranged from 26.78 to $38.83 \mathrm{~g}$ with Bacillus spp., compared to 26.33, 22.10, and $16.05 \mathrm{~g}$ with Micronima ${ }^{\circ}$, medium only, and nematode only, respectively. $B$. subtilis $(40 \mathrm{ml})$ significantly increased the FSW, followed by $B$. pumilus $(40 \mathrm{ml})$, B. subtilis $(30 \mathrm{ml})$, Bacillus sp. $(40 \mathrm{ml})$, Bacillus sp. $(30 \mathrm{ml})$, Bacillus sp. $(20 \mathrm{ml})$, B. subtilis $(20 \mathrm{ml})$, B. pumilus $(30 \mathrm{ml})$, and B. pumilus $(20 \mathrm{ml})$, respectively. The averages of the DSW of eggplants ranged from 2.37 to $8.52 \mathrm{~g}$ with Bacillus spp., compared to $3.38,2.65$, and $2.55 \mathrm{~g}$ with Micronima ${ }^{\circ}$, medium only, and nematode only, respectively. B. pumilus $(40 \mathrm{ml})$ also significantly increased the DSW, followed by $B$. subtilis $(40 \mathrm{ml})$, B. pumilus $(30 \mathrm{ml})$, B. subtilis $(30 \mathrm{ml})$, Bacillus sp. $(40 \mathrm{ml})$, Bacillus sp. $(30 \mathrm{ml})$, B. subtilis $(20 \mathrm{ml})$, Bacillus sp. $(20 \mathrm{ml})$, and B. pumilus $(20 \mathrm{ml})$, respectively (Table 5).

The averages of the eggplant leaf number ranged from 26.00 to 31.50 leaves with Bacillus spp., compared to 23.00, 21.40, and 17.50 leaves with Micronima ${ }^{\circ}$, medium only, and nematode only, respectively. B. pumilus (40 $\mathrm{ml}$ ) significantly increased the leaves, followed by Bacillus sp. $(20 \mathrm{ml})$, Bacillus sp. $(40 \mathrm{ml})$, B. subtilis $(30 \mathrm{ml}), B$. subtilis $(40 \mathrm{ml})$, B. pumilus $(30 \mathrm{ml})$, Bacillus $\mathrm{sp} .(30 \mathrm{ml})$, B. subtilis $(20 \mathrm{ml})$, and B. pumilus $(20 \mathrm{ml})$, respectively. The averages of FRW ranged from 6.13 to $13.20 \mathrm{~g}$ with Bacillus spp., compared to 5.13, 4.53, and $4.45 \mathrm{~g}$ with Micronima ${ }^{\circ}$, medium only, and nematode only, respectively. B. subtilis $(40 \mathrm{ml})$ significantly increased the FRW, followed by B. pumilus $(40 \mathrm{ml})$, Bacillus sp. $(40 \mathrm{ml})$, Bacillus sp. (30 ml), Bacillus sp. $(20 \mathrm{ml})$, B. subtilis (30 $\mathrm{ml})$, B. pumilus $(30 \mathrm{ml})$, B. subtilis $(20 \mathrm{ml})$, and B. pumilus $(20 \mathrm{ml})$, respectively (Table 5$)$.

\section{Experiment III}

Bacillus sp. treatments when applied three times, as a single treatment, with a 7-day interval between each treatment and another, improved the growth parameters of eggplants under greenhouse conditions (Table 6). The average of the SL of eggplants ranged from 34.75 to $50.75 \mathrm{~cm}$, compared to $37.75,28.53$, and $23.55 \mathrm{~cm}$ with Micronima $^{\circ}$, medium only, and nematode only, respectively. B. subtilis (three times) significantly increased the

Table 5 Effects of Bacillus spp. as a single treatment at doses of 20, 30, and $40 \mathrm{ml} /$ pot, on vegetative parameters of eggplants in pots (experiment II)

\begin{tabular}{|c|c|c|c|c|c|c|c|c|c|c|c|}
\hline \multirow{3}{*}{\multicolumn{2}{|c|}{ Bacillus spp. }} & \multicolumn{10}{|c|}{$\underline{\text { Vegetative parameters }}$} \\
\hline & & \multicolumn{2}{|c|}{ Shoot length $(\mathrm{cm})$} & \multicolumn{2}{|c|}{ Shoot fresh weight (g) } & \multicolumn{2}{|c|}{ Shoot dry weight (g) } & \multicolumn{2}{|l|}{ Leaf no. } & \multicolumn{2}{|c|}{ Root fresh weight $(\mathrm{g})$} \\
\hline & & Length (cm) & Inc. $\%$ & Weight (g) & Inc. \% & Weight (g) & Inc. $\%$ & No. & Inc. \% & No. & Inc. \% \\
\hline \multicolumn{2}{|c|}{ Nematode only } & $23.25^{\mathrm{d}}$ & - & $16.05^{\mathrm{d}}$ & - & $2.55^{\mathrm{i}}$ & - & $17.50^{c}$ & - & $4.45^{d}$ & - \\
\hline \multicolumn{2}{|c|}{ NGB Medium only } & $28.55^{\mathrm{cd}}$ & 23 & $22.10^{\mathrm{cd}}$ & 43 & $2.65^{i}$ & 4 & $21.40^{\mathrm{bc}}$ & 20 & $4.53^{d}$ & 2 \\
\hline \multicolumn{2}{|c|}{ Micronima ${ }^{\oplus}$} & $38.25^{b c}$ & 65 & $26.33^{b c}$ & 64 & $3.38^{h}$ & 33 & $23.00^{b c}$ & 31 & $5.13^{d}$ & 15 \\
\hline \multirow[t]{3}{*}{ Bacillus sp. } & $20 \mathrm{ml}$ & $35.75^{b c}$ & 58 & $34.98^{\mathrm{ab}}$ & 118 & $4.04^{g}$ & 58 & $28.75^{a b}$ & 64 & $8.95^{\mathrm{abcd}}$ & 101 \\
\hline & $30 \mathrm{ml}$ & $39.00^{b}$ & 68 & $36.50^{a}$ & 127 & $4.83^{\mathrm{e}}$ & 89 & $26.50^{a b}$ & 51 & $9.70^{\mathrm{abcd}}$ & 119 \\
\hline & $40 \mathrm{ml}$ & $39.50^{b}$ & 70 & $36.90^{a}$ & 130 & $5.75^{d}$ & 126 & $27.50^{a b}$ & 57 & $11.30^{\mathrm{abc}}$ & 154 \\
\hline \multirow[t]{3}{*}{ B. subtilis } & $20 \mathrm{ml}$ & $35.50^{b c}$ & 53 & $33.55^{\mathrm{ab}}$ & 109 & $4.43^{f}$ & 74 & $26.00^{a b}$ & 49 & $6.30^{b c d}$ & 42 \\
\hline & $30 \mathrm{ml}$ & $39.25^{b}$ & 69 & $37.13^{a}$ & 131 & $6.08^{c}$ & 138 & $27.50^{\mathrm{ab}}$ & 57 & $7.73^{\mathrm{abcd}}$ & 74 \\
\hline & $40 \mathrm{ml}$ & $43.25^{b}$ & 86 & $38.83^{a}$ & 142 & $8.52^{b}$ & 234 & $27.00^{a b}$ & 54 & $13.20^{a}$ & 197 \\
\hline \multirow[t]{3}{*}{ B. pumilus } & $20 \mathrm{ml}$ & $40.50^{b}$ & 74 & $26.78^{b c}$ & 67 & $3.27^{\mathrm{h}}$ & 28 & $26.00^{a b}$ & 49 & $6.13^{\mathrm{cd}}$ & 38 \\
\hline & $30 \mathrm{ml}$ & $41.25^{b}$ & 77 & $26.80^{b c}$ & 67 & $8.44^{\mathrm{b}}$ & 231 & $26.75^{a b}$ & 53 & $6.38^{b c d}$ & 43 \\
\hline & $40 \mathrm{ml}$ & $57.50^{a}$ & 147 & $38.65^{a}$ & 141 & $9.62^{a}$ & 277 & $31.50^{\mathrm{a}}$ & 80 & $11.75^{a b}$ & 164 \\
\hline
\end{tabular}

Means followed by different superscript letters are significantly different according to Duncan's multiple range test at $P \leq 0.05$ Inc. increase

*Means are averages of four replicates 
Table 6 Effects of Bacillus spp. as single treatment at different application times at dose $20 \mathrm{ml} /$ pot on vegetative parameters of eggplants in pots (experiment III)

\begin{tabular}{|c|c|c|c|c|c|c|c|c|c|c|c|}
\hline \multirow{3}{*}{\multicolumn{2}{|c|}{ Bacillus spp. }} & \multicolumn{10}{|c|}{ Vegetative parameters } \\
\hline & & \multicolumn{2}{|c|}{ Shoot length (cm) } & \multicolumn{2}{|c|}{ Shoot fresh weight (g) } & \multicolumn{2}{|c|}{ Shoot dry weight (g) } & \multicolumn{2}{|c|}{ No. leaves } & \multicolumn{2}{|c|}{ Root fresh weight (g) } \\
\hline & & Length $(\mathrm{cm})$ & Inc. $\%$ & Weight (g) & No. & Weight (g) & Weight (g) & $\begin{array}{l}\text { Weight } \\
\text { (g) }\end{array}$ & $\begin{array}{l}\text { Inc. } \\
\%\end{array}$ & No. & Inc. \% \\
\hline \multicolumn{2}{|c|}{ Nematode only } & $23.55^{f}$ & - & $16.03^{d}$ & $17.25^{b}$ & $4.50 c$ & $4.50^{c}$ & $4.50^{c}$ & - & $17.25^{\mathrm{b}}$ & - \\
\hline \multicolumn{2}{|c|}{ NGB medium only } & $28.53^{\mathrm{ef}}$ & 21 & $21.98^{\mathrm{cd}}$ & $21.35^{\mathrm{ab}}$ & $4.53 c$ & $4.53^{c}$ & $4.53^{c}$ & 1 & $21.35^{\mathrm{ab}}$ & 24 \\
\hline \multicolumn{2}{|c|}{ Nematode + Micronima ${ }^{\circledast}$} & $37.75^{\text {bcde }}$ & 60 & $26.30^{b c}$ & $23.50^{\mathrm{ab}}$ & $5.15^{c}$ & $5.15^{\mathrm{c}}$ & $5.15^{c}$ & 14 & $23.50^{\mathrm{ab}}$ & 36 \\
\hline \multirow[t]{3}{*}{ Bacillus sp. } & one time & $34.75^{\mathrm{de}}$ & 48 & $28.75^{\mathrm{a}}$ & $4.68^{c}$ & $4.68^{c}$ & 59 & $4.68^{c}$ & 4 & $28.75^{\mathrm{a}}$ & 67 \\
\hline & two times & $42.50^{\mathrm{abcd}}$ & 81 & $28.00^{\mathrm{a}}$ & $4.90^{c}$ & $4.90^{c}$ & 80 & $4.90^{c}$ & 9 & $28.00^{\mathrm{a}}$ & 62 \\
\hline & three times & $44.75^{\mathrm{abc}}$ & 90 & $28.75^{\mathrm{a}}$ & $9.75^{\mathrm{a}}$ & $9.75^{\mathrm{a}}$ & 107 & $9.75^{\mathrm{a}}$ & 117 & $28.75^{\mathrm{a}}$ & 67 \\
\hline \multirow[t]{3}{*}{ B. subtilis } & one time & $35.50^{\text {cde }}$ & 51 & $22.25^{\mathrm{ab}}$ & $4.50^{c}$ & $4.50^{c}$ & 73 & $4.50^{c}$ & 1 & $22.25^{\mathrm{ab}}$ & 29 \\
\hline & two times & $49.00^{a}$ & 108 & $25.25^{\mathrm{ab}}$ & $6.10^{\mathrm{bc}}$ & $6.10^{b c}$ & 120 & $6.10^{b c}$ & 36 & $25.25^{\mathrm{ab}}$ & 50 \\
\hline & three times & $50.75^{a}$ & 116 & $28.75^{a}$ & $7.73^{\mathrm{ab}}$ & $7.73^{\mathrm{ab}}$ & 138 & $7.73^{\mathrm{ab}}$ & 72 & $28.75^{a}$ & 67 \\
\hline \multirow[t]{3}{*}{ B. pumilus } & one time & $40.75^{\mathrm{abcd}}$ & 73 & $25.50^{\mathrm{ab}}$ & $4.68^{c}$ & $4.68^{c}$ & 29 & $4.68^{c}$ & 4 & $25.50^{\mathrm{ab}}$ & 45 \\
\hline & two times & $46.25^{\mathrm{ab}}$ & 96 & $29.75^{a}$ & $6.35^{b c}$ & $6.35^{b c}$ & 179 & $6.35^{b c}$ & 41 & $29.75^{a}$ & 73 \\
\hline & three times & $50.25^{a}$ & 113 & $29.75^{a}$ & $8.40^{\mathrm{a}}$ & $8.40^{\mathrm{a}}$ & 192 & $8.40^{\mathrm{a}}$ & 87 & $29.75^{a}$ & 73 \\
\hline
\end{tabular}

Means followed by different superscript letters are significantly different according to Duncan's multiple range test at $P \leq 0.05$

Inc. increase

*Means are averages of four replicates

average of the SL of eggplants, followed by B. pumilus (three times), B. subtilis (two times), B. pumilus (two times), Bacillus sp. (three times), Bacillus sp. (two times), B. pumilus (one time), B. subtilis (one time), and Bacillus sp. (one time), respectively. The averages of the FSW of eggplants ranged from 26.75 to $39.40 \mathrm{~g}$ with Bacillus spp., compared to 26.30, 21.98, and $16.03 \mathrm{~g}$ with treatments of Micronima ${ }^{\circ}$, medium only, and nematode only, respectively. Bacillus sp. (three times) significantly increased the averages of FSW, followed by B. subtilis (three times), Bacillus sp. (two times), B. subtilis (two times), Bacillus sp. (one time), B. subtilis (one time), B. pumilus (three times), B. pumilus (two times), and $B$. pumilus (one time), respectively. The averages of the DSW of eggplants ranged from 3.28 to $7.44 \mathrm{~g}$ with Bacillus spp., compared to $5.18,4.53,4.53$, and $4.50 \mathrm{~g}$ with treatments of Micronima ${ }^{\circ}$, medium only, and nematode only, respectively. B. pumilus (three times) significantly increased the average of the DSW, followed by B. pumilus (two times), B. subtilis (three times), B. subtilis (two times), Bacillus sp. (three times), Bacillus sp. (two times), B. subtilis (one time), Bacillus sp. (one time), and B. pumilus (one time), respectively (Table 6).

The averages of the eggplant leaf number ranged from 22.75 to 29.75 leaves with Bacillus spp., compared to 23.50, 21.35, and 17.25 leaves with treatments of Micronima ${ }^{\circ}$, medium only, and nematode only, respectively. $B$. pumilus (three times) significantly increased the leaf number, followed by B. pumilus (two times), B. subtilis (three times), Bacillus sp. (three times), Bacillus sp. (one time), Bacillus sp. (two times), B. subtilis (two times), B. pumilus (one time), and B. subtilis (one time), respectively. The averages of the FRW of eggplants ranged from 4.50 to $9.75 \mathrm{~g}$ with Bacillus spp., compared to 5.15, 4.53, and $4.50 \mathrm{~g}$ with Micronima ${ }^{\circ}$, medium only, and nematode only (control), respectively. Bacillus sp. (three times) significantly increased the average of the FRW, followed by B. pumilus (three times), B. pumilus (two times), B. subtilis (three times), B. subtilis (two times), Bacillus sp. (two times), Bacillus sp. (one time), B. pumilus (one time), and B. subtilis (one time), respectively (Table 6).

\section{Discussion}

The root-knot nematode, M. incognita, is one of the most soil-borne pathogens which attack a wide range of crops (Kavitha et al. 2012). The application of chemicals continues to be the major tactic to mitigate crop diseases that cause hazards to human and the environment. Therefore, the use of biocontrol agents to suppress soil-borne disease-causing activity of plant pathogens is very important, where biological agents could colonize the plant rhizosphere, suppress the disease through several mechanisms, viz. antibiosis, competition, myco-parasitism, and cell wall degradation, and induce resistance, as well as produce the plant growth promotion (Junaid et al. 2013). Pseudomonas or Bacillus could colonize the rhizosphere of plants in, on, or around plant tissues, stimulate plant growth, and reduce nematode populations by antagonistic behavior. The application of some of these bacteria recorded promising results. Their beneficial events could be a biological 
control of a nematode, plant growth promotion, and increase in crop yields and quality (Akhtar et al. 2012).

In this work, the combination treatment between Bacillus spp., especially in two pairs, highly reduced more the tested nematode parameters than in a single treatment or three pairs. The two pair combination differed in suppressive activity against nematode, where Bacillus sp. mixed with $B$. subtilis highly reduced the $\mathrm{J}_{2}$ in soil, galls, and the number of egg masses, while Bacillus sp. mixed with $B$. pumilus highly reduced the $J_{2}$ in roots. It may be due to the antagonistic effect of a single treatment. Bacillus spp., when applied as single at different doses, were more effective against nematode parameters, where their nematicidal activity was increased by increasing the applied dose. It was clear with the application of a dose $(40 \mathrm{ml} / \mathrm{pot})$. The same trend was noticed when Bacillus spp. applied at different times, where the nematicidal effect of the tested bacteria was increased with increased time of application. Our results suggest that the application of Bacillus spp. in two pairs was more effective in reducing tested nematode parameters. The nematicidal activity of Bacillus spp. increased with the increase of the used dose as well as the increase of the time of application.

These results are in agreement with the colonization of plant roots by non-pathogenic bacteria that can induce systemic resistance to pathogen infections in plants (Siddiqui and Shauka 2003; Rahanandeh and Moshaiedy 2014). Bacillus spp. also have a wide distribution of cuticle-degrading proteases that play an important role as a nematicidal factor in balancing nematode populations in the soil (Lian et al. 2007). B. amyloliquefaciens, B. subtilis, B. pasteurii, B. cereus, B. pumilus, $B$. mycoides, and $B$. sphaericus elicit significant reductions of root-knot nematodes (Choudhary and Johri 2009), where colonization of plant roots is an essential step for both soil-borne pathogenic and beneficial rhizobacteria. Our results are in agreement with microbes that could be a biological control indirectly by reducing the level of disease which includes antibiosis, induction of systemic resistance, and competition for nutrients and niches (Lugtenberg and Kamilova 2009). Bacillus lipopeptides, producing surfactins, iturins, and fengycins, have antagonistic activity against a wide range of phytopathogens which include nematodes. $B$. subtilis also highly produced surfactin and iturin activity that could suppress egg hatching and kill the $\mathrm{J}_{2}$ of $M$. incognita under in vitro condition (Kavitha et al. 2012). The strain of Bacillus alvei showed potentiality against the nematode's eggs and larvae, where the strain used hydrolytic enzymes to directly hydrolyze the nematode's eggs and larvae. The action of the strain or its metabolites against eggs and larvae is also associated with the release of high levels of reducing sugars and lytic enzymes, viz. chitinase, chitosanase, and proteases (Abdel-Aziz et al. 2013).
In this work, the application of Bacillus spp. as single or in combination resulted in a variable increase in tested growth parameters, where treatments in two pairs or three pairs showed that the Bacillus spp. increased the shoot length or shoot dry weight, compared with the single treatment. Bacillus sp. mixed with B. subtilis was the most effective in increasing the tested growth parameters. Results showed that Bacillus spp. at a high dose $(40 \mathrm{ml})$ were more enhanced in the tested growth parameters than the other doses. B. pumilus $(40 \mathrm{ml})$ highly increased all tested growth parameters except the shoot fresh weight, while B. subtilis $(40 \mathrm{ml})$ highly increased the shoot fresh weight. Results showed that the frequency of application of Bacillus spp. highly increased the growth parameters of eggplants except for the root fresh weight compared with the medium only and nematode only.

These results are in agreement with the rhizobacteria that are capable of stimulating plant growth through a variety of mechanisms that include the improvement of plant nutrition, production, and regulation of phytohormones and suppression of disease-causing organisms (Martínez-Viveros et al. 2010). The inoculation of crop plants with PGPR strains at an early stage of development improves biomass production through direct effects on root and shoot growth as well as enhance the seedling germination, stand health, plant vigor, plant height, shoot weight, nutrient content of shoot tissues, early bloom, chlorophyll content, and increased nodulation in legumes (Saharan and Nehra 2011). PGPR are beneficial bacteria that could colonize the plant rhizosphere which resulted in an enhancement of root length, shoot fresh, and dry weight/plant on plants infected with M. incognita (El-Sayed and Edrees 2014). The microbes are directly beneficial to plant growth by means of biofertilization, stimulation of root growth, rhizoremediation, and plant stress control (Lugtenberg and Kamilova 2009).

\section{Conclusions}

The biocontrol agents used more than once or in combination are more effective than those used only once in controlling nematode parameters and thus increased the growth parameters compared to the controls. However, it is necessary to further affirm these results and investigate various mechanisms involved that are caused by the studied bacterial isolates under field conditions.

\section{Abbreviations}

ANOVA: Analysis of variance; $B$. amyloliquefaciens: Bacillus amyloliquefaciens; $B$. cereus: Bacillus cereus; B. mycoides: Bacillus mycoides; B. pasteurii: Bacillus pasteurii; B. pumilus: Bacillus pumilus; $B$. sphaericus: Bacillus sphaericus; $B$. subtilis: Bacillus subtilis; $B$. thuringiensis: Bacillus thuringiensis; $B$. weihenstephanensis: Bacillus weihenstephanensis; CFU: Colony-forming unit; DMRT: Duncan's multiple range test; DSW: The averages of dry shoot weight; FRW: The averages of fresh root weight; FSW: The averages of fresh shoot weight; Inc.: Increase; $J_{2}$ : Second-stage juveniles; M. incognita: Meloidogyne 
incognita; NGB: Nutrient Glucose Beef Extract; P. fluorescens: Psudomonas fluorescens; PGPR: Plant growth-promoting rhizobacteria; Red.: Reduction; $S$. marcescens: Serratia marcescens; SL: The averages of shoot length

\section{Acknowledgements}

This research work was supported in part by the in-house project no. 10120603 entitled "Improving Activity of some Microorganisms through Biotechnological Approaches to Control plant Parasitic Nematodes" in National Research Centre, Egypt.

\section{Authors' contributions}

All authors read and approved the final manuscript.

\section{Funding}

There is no funding.

\section{Availability of data and materials}

The tested bacterial isolates and nematodes are available in the Egyptian environment and were identified in the laboratory.

\section{Ethics approval and consent to participate}

Not applicable.

\section{Consent for publication}

Not applicable.

\section{Competing interests}

The authors declare that they have no competing interests.

Received: 7 August 2019 Accepted: 4 September 2019

Published online: 29 October 2019

\section{References}

Abbasi MW, Ahmed N, Zaki MJ, Shuakat SS, Khan D (2014) Potential of Bacillus species against Meloidogyne javanica parasitizing eggplant (Solanum melongena L.) and induced biochemical changes. Plant Soil 375:159-173

Abdel-Aziz Shadia M, El-Nagdi Wafaa MA, Moharam Maysa E (2013) Efficiency of the novel strain Bacillus alvei NRC -14 for biocontrol of parasitic nematode. J Agric Food Tech 3(12):31-40

Abd-El-Khair H, El-Nagdi Wafaa MA, Ameen Hoda H (2016) Antagonistic effects of rhizobacteria isolates against Meloidogyne incognita infecting tomato plants under greenhouse conditions. Int J Pharm Tech Research 9(10):97-107

Ahemad M, Kibret M (2014) Mechanisms and applications of plant growth promoting rhizobacteria: current perspective. J King Saud Univ Sci 26(1):1-20

Akhtar A, Hisamuddin Ml, Abbasi SR (2012) Plant growth promoting rhizobacteria: an overview. J Nat Prod Plant Resour 2(1):19-31

Barker TR (1985) Nematode extraction and bioassays. Pp 19-35. In: Barker TR, Carter CC, Sasser JN (eds) An Advanced Treatise on Meloidogyne Vol. II. North Carolina State University, USA

Choudhary DK, Johri BN (2009) Interactions of Bacillus spp. and plants with special reference to induced systemic resistance (ISR). Microbiol Res 164(5):493-513

El-Sayed IA, Edrees Nada O (2014) Using of plant growth promoting rhizobacteria as biocontrol agent for root-knot nematode under greenhouse. Nat Sci 12(12):41-49

El-Nagdi Wafaa MA, Abd-El-Khair H (2008) Biological control of Meloidogyne incognita and Rhizoctonia solani in eggplant. Nematol Medit 36:85-92

El-Nagdi Wafaa MA, Abd-El-Khair H, Dawood Mona G (2018) Nematicidal effects of Bacillus subtilis and Bacillus pumilus against Meloidogyne incognita infecting pea. Adv Agric Sci 6(4):52-59

El-Nagdi Wafaa MA, Youssef MMA, Abd-El-Khair H, Abd Elgawad MMM, Dawood Mona G (2019) Effectiveness of Bacillus subtilis, B. pumilus, Pseudomonas fluorescens on Meloidogyne incognita infecting cowpea. Pak J Nematol 37(1):35-43

Farfour SA, El-Ansary M SM (2013) Suppression of root-knot nematode (Meloidogyne incognita) on eggplant by applying some biofertilizers and biocontrol agents. Egypt J Agronematol 12(1):63-73

Gu YQ, Zhou JP, Zou CS, Mo MH, Zhang KQ (2007) Evaluation and identification of potential organic nematocidal volatiles from soil bacteria. Soil Biol Biochem 39:2567-2575
Hussey RS, Barker RK (1973) A comparison of methods of collecting inocula of Meloidogyne spp. including a new technique. Plant Dis Rep 57:1025-1028

Junaid JM, Dar NA, Bhat TA, Bhat AH, Bhat MA (2013) Commercial biocontrol agents and their mechanism of action in the management of plant pathogens. Int J Mod Plant Anim Sci 1(2):39-57

Karmani BK, Jiskani MM, Khaskheli MI, Wagan KH (2011) Influence of organic amendments on population and reproduction of root knot nematode, Meloidogyne incognita in eggplants. Pak J Agri Agril Engg Vet Sci 27(2):150-159

Kavitha PG, Jonathan El, Nakkeeran S (2012) Effects of crude antibiotic of Bacillus subtilis on hatching of eggs and mortality of juveniles of Meloidogyne incognita. Nematol Medit 40:203-206

Lian LH, Tian BY, Xiong R, Zhu MZ, Xu J, Zhang KQ (2007) Proteases from Bacillus: a new insight into the mechanism of action for rhizobacterial suppression of nematode populations. Lett Appl Microbiol. https://doi.org/10.1111/j.1472765X.2007.02184.X

Lugtenberg B, Kamilova F (2009) Plant-growth-promoting rhizobacteria. Annu Rev Microbiol 63:541-556

Martínez-Viveros O, Jorquera MA, Crowley DE, Gajardo G, Mora ML (2010) Mechanisms and practical considerations involved in plant growth promotion by rhizobacteria. J Soil Sci Plant Nutr 10(3):293-319

Mokbel Asmaa A, Alharbi Asmaa A (2014) Suppressive effect of some microbial agents on root-knot nematode, Meloidogyne javanica infected eggplant. Aust J Crop Sci 8(10):1428-1434

Rahanandeh H, Moshaiedy M (2014) Potency evaluation of Pseudomonas aeroginosae and Pseudomonas fluorescens as biocontrol agents for root - knot nematodes in Iran. Int J Biosci 4(12):222-228

Saharan BS, Nehra V (2011) Plant growth promoting rhizobacteria: a critical review. Life Sci Med Res 21:1-33

Serfoji P, Rajeshkumar S, Selvaraj T (2010) Management of root-knot nematode, Meloidogyne incognita on tomato cv Pusa ruby by using vermicompost, AM fungus, Glomus aggregatum and mycorrhiza helper bacterium, Bacillus Coagulans. J Agric Technol 6(1):37-45

Siddiqui IA, Shauka SS (2003) Role of salicylic acid in Pseudomonas aeruginosa strain IE-6S+-mediated induction of systemic resistance against Meloidogyne Javanica in tomato. Phytopathol Mediterr 42:268-274

Sivasakthi S, Usharani G, Saranraj P (2014) Biocontrol potentiality of plant growth promoting bacteria (PGPR) - Pseudomonas fluorescens and Bacillus subtilis: a review. Afr J Agric 9(16):1265-1277

Snedecor GW, Cochran WG (1999) Statistical methods, 5th edn. lowa State Univ. Press, Ames (IA), p 593

Tamalika S, Ramakrishnan S, Nakkeeran S (2014) Biocontrol potential of endophytic Bacillus spp. against Meloidogyne incognita in tomato. Int J Trop Agric 32(1/2):19-26

Taylor, A.L. and Sasser, J.N. (1978). Biology, identification and control of root-knot nematodes (Meloidogyne species). Raleigh (NC): IMP, North Carolina State University Graphics

Usman A, Siddiqui MA (2012) Effect of some fungal strains for the management of root-knot nematode (Meloidogyne incognita) on eggplant (Solanum melongena). J Agric Techn 8(1):213-218

Zaghloul RA, Neweigy NA, Abou-Aly HE, El-Sayed SA, Bahloul AM (2015) Nematicidal activity of some biocontrol agents against root-knot nematodes in-vitro. Res J Pharm Biol Chem Sci 6(1):429-438

\section{Publisher's Note}

Springer Nature remains neutral with regard to jurisdictional claims in published maps and institutional affiliations. 